\title{
Editorial
}

\section{Small Steps in Knowledge to Better Care and Quality of Life}

\author{
Helena Canhão ${ }^{a}$ João A. Pereirab \\ ${ }^{a}$ NOVA Medical School, NOVA University Lisbon, Lisbon, Portugal; ${ }^{b}$ NOVA National School of Public Health, \\ NOVA University Lisbon, Lisbon, Portugal
}

\section{Pequenos passos para o conhecimento sobre melhores cuidados e melhor qualidade de vida}

Welcome to the 2018 second issue of the Portuguese Journal of Public Health (PJPH). The journal's editorial team, reviewers, authors, and readers are committed to furthering new knowledge, discussion, and advancements in the fields of public health, epidemiology, and health care policy and management [1].

This issue proves that we are managing to do so, with a variety of interesting papers, developed in different settings and contexts. In fact, each and every paper presents a discussion of current issues either by examining social aspects of different interventions or by presenting proposals for innovative policies and new organizational approaches in public health.

As from 2019, all papers published in PJPH will be in English, thereby widening readership beyond the Lusophone world, but the current issue still contains some articles in Portuguese. We hope that readers will learn from the papers published, enjoy reading them, and are stimulated to take knowledge further in the various areas that are covered.

Fernanda Daniel et al. [2] studied a sample of 300 elderly persons in the Municipality of Lousã in Portugal to

\section{KARGER}

E-Mail karger@karger.com www.karger.com/pjp

Karger

Open access (c) 2018 The Author(s). Published by S. Karger AG, Basel on behalf of NOVA National School of Public Health

This article is licensed under the Creative Commons AttributionNonCommercial-NoDerivatives 4.0 International License (CC BYNC-ND) (http://www.karger.com/Services/OpenAccessLicense). Usage and distribution for commercial purposes as well as any distribution of modified material requires written permission. measure quality of life in older people according to their gender. Drawing on the Portuguese version of EQ-5D-3L, they find that women report a lower quality of life, with statistically significant associations in 4 of the 5 dimensions of the measuring instrument (self-care, usual activities, pain/discomfort, and anxiety/depression). They argue that this evidence should be taken into consideration when devising ageing health and social care strategies.

Marta Alves and colleagues [3] present an important hot topic: measuring empowerment in patients with chronic disease. They evaluated the psychometric qualities of the Portuguese Rheumatic Disease Empowerment Scale (P-RES-8) and show that the instrument is valid and reliable as a measure of perception of empowerment in patients with rheumatic disease. They also find that empowerment is positively related to quality of life, higher education, and longer-term experience of illness.

The relationships, connections, and communication between primary care and hospitals are sometimes not as smooth as they should be. Maria Margarida Costa Ferreira Bandarra et al. [4] address this subject by asking if there is a role for primary care in the follow-up of colorectal cancer patients? Drawing on data from a large hospital in Lisbon, they find that the follow-up of colorectal cancer patients is associated with significant hospital resources 
and physician time. They argue that other follow-up models should be considered as an alternative to traditional hospital-centered follow-up, namely that of sharedcare follow-up, which requires a multidisciplinary and survivor-centered approach.

Victor P. Gavina et al. [5] discuss the subject of oral health for patients with special needs. They evaluate Dental Specialty Centers in the mountain region of Rio de Janeiro State, Brazil, using mixed methods research and find that most patients with special needs as well as the persons who accompanied them were satisfied with the services provided. The results of the study also show the importance of human relations between professionals and patients, suggesting a need for managers and health care teams to perform quality evaluation of their services from the point of view of patients.

Mario J. Setumba et al. [6] focus their work on the challenges associated with managing low-weight newborns in Angola. Their retrospective study of 2,100 low-birthweight infants found high levels of neonatal mortality associated with maternal age, diseases during pregnancy, and low adherence to prenatal consultations. According to the authors, a significant number of deaths among lowbirth-weight infants are preventable through adequate prenatal care, delivery, birth, and follow-up, as well as through fair access to health care and qualified professional intervention.

Ana Resende and her coauthors [7] close the issue with an important review about practices of family literacy by presenting an educational strategy for the health and integral development of the child. The authors argue that there is currently a new vision involving not only the child but also the family and the parents in particular. These are now regarded as key elements to be mobilized as early as possible in primary health care interventions.

The diversity and quality of the articles published in this issue speak for themselves as readers will find in the following pages. Knowledge, ideas, and debate are crucial to the advancement of modern societies. Public health and clinical research in different settings, different regions, different specialties, and different populations are the foundations to ultimately improve care and quality of life. Public health, research, and clinical papers are small steps that contribute to this journey. Enjoy!

\section{References}

1 Pereira J, Canhão H. The Portuguese Journal of Public Health - A New Direction. Port J Public Health. 2017;35(1):1-2.

2 Daniel F, Monteiro R, Antunes S, Fernandes R, Ferreira PL. Qualidade de vida relacionada com a saúde de pessoas idosas numa perspetiva de género. Port J Public Health. doi: 10.1159/000490929.

3 Alves MP, Cunha A, Lopes T, Abreu P, Vaz CI, Lopes T, et al. Measuring Empowerment in Patients with Chronic Disease: Psychometric Qualities of the Portuguese Rheumatic
Disease Empowerment Scale. Port J Public Health. doi: 10.1159/000492084.

4 Costa Ferreira Bandarra MM, Escoval A, Marques da Costa L. Is There a Role for Primary Care in the Follow-Up of Colorectal Cancer Patients? The Case of a Portuguese University Hospital. Port J Public Health. doi: 10.1159/000492345.

5 Gavina VP, Alves N, Alves FR, Cortellazzi KL, Silveira FM, Assaf AVS, et al. Oral Health for Patients with Special Needs: Evaluative Research of the Dental Special- ties Centers. Port J Public Health. doi: $10.1159 / 000493886$.

6 Setumba MJ, Simão M, Silva MC, Scochi CG, Pina JC, Mello DF. Mortalidade em recémnascidos de baixo peso ao nascer: limites e desafios para o acesso universal. Port J Public Health. doi: 10.1159/000493959.

7 Resende A, Figueiredo MH. Práticas de literacia familiar: uma estratégia de educação para a saúde para o desenvolvimento integral da criança. Port J Public Health. doi: 10.1159/ 000492265 . 